International Business and Global Economy 2018, no. 37, pp. 114-127

Biznes międzynarodowy w gospodarce globalnej 2018, nr 37, s. 114-127

Edited by the Institute of International Business, University of Gdańsk

\title{
Taksonomiczna analiza zrównoważonego rozwoju Litwy w sferze społecznej w latach 2006-2016
}

Celem opracowania była ocena zróżnicowania poziomu ładu społecznego w kontekście zrównoważonego rozwoju w okręgach Litwy w latach 2006-2016. Do analizy wykorzystano metody porządkowania liniowego, które pozwoliły na zaprezentowanie dynamiki i trendu zmian poziomu ładu społecznego w badanym okresie. Syntetyczne mierniki ładu społecznego dla okręgów Litwy wyznaczone metodą Hellwiga pozwoliły na porównanie pozycji okręgów pod kątem osiąganego przez nie ładu społecznego. Zaobserwowano wzrost ogólnego poziomu zrównoważonego rozwoju w wymiarze społecznym, przy jednoczesnym wzroście zróżnicowania ze względu na ten wymiar między okręgami Litwy w latach 2006-2016. Najniższy poziom zrównoważonego rozwoju w sferze społecznej w większości okręgów odnotowano w latach 2009-2010 oraz 2014-2015. Najwyższy rozwój sfery społecznej w badanym okresie zaobserwowano w okręgu wileńskim, średni wyższy w okręgu kowieńskim i kłajpedzkim. W opracowaniu wykorzystano dane Departamentu Statystyki Litwy.

Słowa kluczowe: rozwój zrównoważony, ład społeczny, metody wielowymiarowej analizy, metoda Hellwiga

Klasyfikacja JEL: C1, Q01, R11

\section{Taxonomic analysis of sustainable development of Lithuania in the social dimension in 2006-2016}

The study concerned the assessment of the diversity of the level of social order in the context of sustainable development in the districts of Lithuania in 2006-2016. The use of the linear ordering method allowed to present the dynamics and the trend of changes in the examined period. By constructing synthetic measures of social order for Lithuania's districts, the Hellwig method compared the positions of districts due to the level of social order achieved. Overall, the level of sustainable development in the social dimension for Lithuania's districts in 2006-2016 increased. There was also an increase in the diversity of the level of sustainable development between the districts. The lowest level of sustainable development in the social dimension for the majority of districts was recorded in 2009-2010 and 2014-2015. The highest development of the social sphere in the analysed period was recorded in the Vilniaus district, and a medium-high level in districts Kauno and Klaipedos. The study uses data from the Lithuanian Statistics Department.

Keywords: sustainable development, social order, multidimensional comparative analysis, Hellwig method

JEL classification: C1, Q01, R11 


\section{Wprowadzenie}

Elementy filozofii zrównoważonego rozwoju to efektywność ekonomiczna wszelkiej ludzkiej działalności, odpowiedzialność za jakość życia społecznego i ochrona zasobów środowiska [Ponikowski, 2007, s. 14]. Zrównoważony rozwój to zjawisko wielowymiarowe, definiowane jako harmonijny proces osiągania celów: ekologicznych, ekonomicznych, społecznych i humanitarnych [Dobrzańska, 2006, s. 225]. Wymiar społeczny trwałego rozwoju wyraża się w społecznej akceptacji rezultatów prowadzonej polityki społeczno-gospodarczej. Różnorodność definicji trwałego rozwoju i różnych jego wymiarów wskazuje na wagę społecznych problemów, które muszą pozostawać w kręgu zainteresowań zrównoważonego rozwoju [Kozłowski, 2008; Sachs, 2004; Pearce, 1987]. W ramach koncepcji trwałego rozwoju człowiek może być traktowany jako cel, gdyż z jednej strony degraduje środowisko, a z drugiej konsumuje skutki tej działalności. A więc istotę polityki państwa w sferze społecznej stanowi podniesienie poziomu świadomości społeczeństwa.

Wdrażanie koncepcji zrównoważonego rozwoju na Litwie na szczeblu krajowym zostało zapoczątkowane w 2000 r. powstaniem Państwowej Komisji Zrównoważonego Rozwoju. W 2003 r. rząd Litwy zatwierdził państwową strategię zrównoważonego rozwoju, w której sformułowano podstawowe długo-, średnioi krótkookresowe cele oraz zadania, jak również narzędzia niezbędne do ich osiągnięcia. W ramach strategii opracowano zestaw wskaźników pozwalający monitorować środowiskową, ekonomiczną i społeczną sferę zrównoważonego rozwoju Litwy. 8 kwietnia 2011 r. uchwałą rządu litewskiego została zatwierdzona poprawiona wersja strategii zrównoważonego rozwoju, obejmująca nowy system monitorujących wskaźników wdrażania tej strategii [Dz. U. 2003, nr 89-4029, poz. 1160, z późn. zm.].

Pomiar oraz monitorowanie realizacji koncepcji zrównoważonego rozwoju $\mathrm{w}$ regionach to temat podejmowany $\mathrm{w}$ wielu pracach naukowych [Roszkowska, Filipowicz-Chomko, 2016; Perło, 2014; Roszkowska, Karwowska, 2014; Bartniczak, 2012; Perło, Roszkowska, 2011; Bell, Morse, 2000; Dobrzańska, 2006; Wskaźniki Zrównoważonego Rozwoju, 2016]. Również aspekty zrównoważonego rozwoju Litwy były przedmiotem badań nie tylko na szczeblu lokalnym, ale i krajowym [Štreimikienė, 2014; Čiegis, 2008; Čiegis, 2004; Galkute, 2005; Paulikas, Lazdinis, 2006; Krankalis, 2010; Barasaite, 2016; Mazajevaite், 2016; Darnaus vystymosi tikslai, 2016], brakuje jednak kompleksowej analizy poziomu zróżnicowania trwałego rozwoju Litwy ze względu na ład społeczny, środowiskowy i gospodarczy w ujęciu czasowym i przestrzennym.

Celem artykułu jest ocena realizacji koncepcji zrównoważonego rozwoju ze względu na wymiar społeczny w okręgach Litwy w latach 2006-2016, przeprowa- 
dzona z wykorzystaniem metod taksonomicznych. Istotą taksonomii są analiza i porządkowanie obiektów opisanych za pomocą zmiennych. Stosowanie metod taksonomicznych w statystyce regionalnej pomaga zbadać efektywność osiąganych rezultatów i zróżnicowanie badanych obiektów ze względu na zjawiska społeczno-gospodarcze [Młodak, 2006]. Do oceny zróżnicowania poziomu rozwoju w sferze społecznej wykorzystano indywidualne wskaźniki, budując syntetyczny wskaźnik miary zrównoważonego rozwoju w wymiarze społecznym. Dobór wskaźników dla okręgów oparto na wskaźnikach monitorujących wdrażanie strategii zrównoważonego rozwoju na Litwie. Posłużono się głównie metodą porządkowania liniowego Hellwiga. Przegląd merytoryczny prac analizujących pomiar zrównoważonego rozwoju miał wpływ na końcowy dobór danych wskaźników indywidualnych, użytych do skonstruowania syntetycznego miernika. W opracowaniu wykorzystano dane Departamentu Statystyki Litwy.

\section{Metoda badania}

Ocena zróżnicowania poziomu trwałego rozwoju okręgów Litwy ze względu na sferę społeczną w latach 2006-2016 została dokonana na podstawie wskaźników indywidualnych i syntetycznego miernika wyznaczonego metodą Hellwiga. Etapy badania były następujące:

1. Ustalono listę indywidualnych wskaźników i określono ich charakter, dzieląc na stymulanty i destymulanty ${ }^{1}$. Na podstawie przesłanek merytorycznych i dostępności informacji statystycznej określono zbiór 21 indywidualnych wskaźników (tab. 1). Wskaźniki reprezentujące poziom zrównoważonego rozwoju w okręgach Litwy w sferze społecznej pogrupowano w podobszary tematyczne: „zmiany demograficzne”, „zdrowie publiczne”, „integracja społeczna”, "dostęp do rynku pracy”, , edukacja”, , ,bezpieczeństwo publiczne" i „zrównoważona konsumpcja". Przestrzenny zakres badań dotyczył okręgów Litwy, natomiast zakres czasowy objął lata 2006-2016.

2. Zweryfikowano wskaźniki ze względu na ich własności statystyczne, takie jak: uniwersalność, porównywalność w czasie i przestrzeni, słabe wzajemne skorelowanie (w celu uniknięcia powielania informacji), duża zmienność (współczynnik zmienności powyżej 10\%) [Młodak, 2006; Strahl, 2006; Nowak, 1990].

3. Kolejny etap dotyczył normalizacji wskaźników diagnostycznych zgodnie z formułą unitaryzacji zerowanej [Malina, 2014, s. 32-35]. Dla porównania wielkości w czasie wzięto wspólny wzorzec:

1 Nominanty zostały w danym badaniu pominięte. W przypadku ich występowania zaliczono je do stymulant. 
$\begin{aligned} \text { a) dla stymulant: } \quad z_{i k t} & =\frac{s_{i k t}-\min _{i}\left\{s_{i k t}\right\}}{\max _{i}\left\{s_{i k t}\right\}-\min _{i}\left\{s_{i k t}\right\}} \\ \text { b) dla destymulant: } z_{i k t} & =\frac{\max _{i}\left\{s_{i k t}\right\}-s_{i k t}}{\max _{i}\left\{s_{i k t}\right\}-\min _{i}\left\{s_{i k t}\right\}}\end{aligned}$

gdzie:

$i \quad$ - numer okręgu $(i=1,2, \ldots, n=10)$,

$k$ - numer wskaźnika zrównoważonego rozwoju w sferze $\operatorname{społecznej~}(k=1$, $2, \ldots, \mathrm{m})$,

$t \quad-\operatorname{rok}(t=2006,2007, \ldots, 2016)$,

$\max _{i}\left\{s_{i k t}\right\}$ - maksymalna wartość $k$-tego wskaźnika trwałego rozwoju w wymiarze społecznym w latach 2006-2016,

$\min _{i}\left\{s_{i k t}\right\}$ - minimalna wartość $k$-tego wskaźnika trwałego rozwoju w wymiarze społecznym w latach 2006-2016.

4. Obliczono odległość euklidesową okręgów od wzorca rozwoju $z^{+}(1,1, \ldots, 1)$ według wzoru:

$$
d_{i t}^{+}=\sqrt{\sum_{k=1}^{m}\left(z_{i k t}-z_{k}^{+}\right)}
$$

5. Wyznaczono wartości syntetycznego miernika zrównoważonego rozwoju w sferze społecznej dla $i$-tego okręgu oraz $t$-tego roku według wzoru:

$$
q_{i t}=1-\frac{d_{0 i t}}{d_{0 t}}
$$

gdzie:

$i \quad$ numer okręgu $(i=1,2, \ldots, n=10)$,

$t \quad-\operatorname{rok}(t=2006,2007, \ldots, 2016)$,

$d_{0 i t} \quad$ - odległość od wzorca rozwoju dla $i$-tego okręgu $(i=1,2, \ldots, n=10)$ w $t$-tym roku $(t=2006,2007, \ldots, 2016)$,

$d_{0 t}$ - odległość wzorcowa w $t$-tym roku $(t=2006,2007, \ldots, 2016)$,

$q_{\text {it }} \quad$ - wartość syntetycznej miary dla $i$-tego okręgu $(i=1,2, \ldots, n=10) \mathrm{w}$-tym roku $(t=2006,2007, \ldots, 2016)$.

Odległość wzorcową wyznacza się ze wzoru:

gdzie:

$$
d_{0 t}=\bar{d}_{t}+2 s_{d t}
$$

$\bar{d}_{t}$ - przeciętna odległość między obiektami a wzorcem rozwoju w $t$-tym $\operatorname{roku}(t=2006,2007, \ldots, 2016)$, wyznaczona według wzoru: $\bar{d}_{t}=\frac{1}{n} \sum_{i=1}^{n} d_{0 i t}$,

$s_{d t}-$ odchylenie standardowe $\mathrm{w} t$-tym roku $(t=2006,2007, \ldots, 2016)$, wyznaczone według wzoru: $s_{d t}=\sqrt{\frac{1}{n} \sum\left(d_{0 i t}-\bar{d}_{t}\right)^{2}}$. 
Wartości syntetycznego miernika należą do przedziału $<0,1>$. Wyższe wartości syntetycznego miernika świadczą o wyższej pozycji okręgu w danym rankingu.

6. Uporządkowano liniowo okręgi Litwy ze względu na wartość syntetycznego miernika zrównoważonego rozwoju w sferze społecznej oraz podzielono okręgi na cztery klasy. Wykorzystując średnią arytmetyczną $\left(\bar{q}_{t}\right)$ i odchylenie standardowe $\left(s_{q t}\right)$ dla wartości syntetycznego miernika zrównoważonego rozwoju w sferze społecznej, dokonano podziału okręgów na cztery klasy dla $t$-tego roku w latach 2006-2016 zgodnie ze wzorami:

- klasa I (poziom wysoki): $q_{i t} \geq \bar{q}_{t}+s_{q t}$,

- klasa II (poziom średni wyższy): $\bar{q}_{t}+s_{q t}>q_{i t} \geq \bar{q}_{t}$,

- klasa III (poziom średni niższy): $\bar{q}_{t}>q_{i t} \geq \bar{q}_{t}-s_{q t}$,

- klasa IV (poziom niski): $q_{i t}<\bar{q}_{t}-s_{q t}$.

Dany podział posłużył do określenia poziomu zrównoważonego rozwoju Litwy w sferze społecznej w ujęciu przestrzennym i czasowym.

7. Grupowanie okręgów do typologicznych klas poziomu zrónoważonego rozwoju w wymiarze społecznym poddano ocenie zdolności dyskryminacyjnych skonstruowanych mierników. W tym celu wyznaczono współczynnik $G_{t}$ Sokołowskiego [Sokołowski, 1984]:

$$
G_{t}=1-\sum_{i=1}^{n-1} \min \left\{\frac{q_{i t}-q_{i+1, t}}{R}, \frac{1}{n-1}\right\}
$$

gdzie:

$R_{t}=\max _{i}\left\{q_{i t}\right\}-\min _{i}\left\{q_{i t}\right\}$,

$q_{i t}, q_{i+1, t}-$ uporządkowane niemalejąco wartości miernika.

Wskaźnik $G_{t}$ przyjmuje wartości z przedziału $\left[0 ; 1-\frac{1}{n-1}\right]$. Wysokie wartości wskaźnika dowodzą dużej zdolności miernika taksonomicznego do grupowania.

\section{Ocena zróżnicowania poziomu rozwoju okręgów Litwy} w sferze społecznej trwałego rozwoju w latach 2006-2016

Początkowy zestaw indywidualnych wskaźników objaśniających rozwój zrównoważony w wymiarze społecznym składał się z 21 wskaźników, pogrupowanych w podobszary tematyczne: „zmiany demograficzne”, ,zdrowie publiczne”, „integracja społeczna”, „dostęp do rynku pracy”, „edukacja”, „bezpieczeństwo publiczne” i „zrównoważona konsumpcja” (tab. 1). 
Tabela 1. Wskaźniki indywidualne charakteryzujące wymiar społeczny zrównoważonego rozwoju okręgów Litwy w latach 2006-2016

\begin{tabular}{|c|c|c|c|}
\hline $\begin{array}{l}\text { Podobszar } \\
\text { tematyczny }\end{array}$ & $\begin{array}{l}\text { Nazwa } \\
\text { wskaźnika }\end{array}$ & Opis wskaźnika & Charakter \\
\hline \multirow{4}{*}{$\begin{array}{l}\text { Zmiany } \\
\text { demogra- } \\
\text { ficzne }\end{array}$} & S1 & $\begin{array}{l}\text { przyrost naturalny wyznaczany jako relacja urodzeń } \\
\text { żywych do zgonów }\end{array}$ & $\mathrm{S}$ \\
\hline & S2 & współczynnik dzietności & S \\
\hline & S3 & demograficzny wskaźnik starości & $\mathrm{D}$ \\
\hline & S4 & $\begin{array}{l}\text { saldo migracji wyznaczane jako zameldowania ogółem } \\
\text { w stosunku do wymeldowań ogółem }\end{array}$ & $\mathrm{S}$ \\
\hline \multirow{4}{*}{$\begin{array}{l}\text { Zdrowie } \\
\text { publiczne }\end{array}$} & S5 & zgony niemowląt na 1 tys. urodzeń żywych & $\mathrm{D}$ \\
\hline & S6 & $\begin{array}{l}\text { standaryzowany współczynnik umieralności z powodu } \\
\text { chorób układu krążenia i nowotworów złośliwych }\end{array}$ & $\mathrm{D}$ \\
\hline & S7 & liczba lekarzy na 10 tys. mieszkańców & $\mathrm{S}$ \\
\hline & S8 & liczba zachorowań szpitalnych na 1 tys. mieszkańców & $\mathrm{D}$ \\
\hline \multirow{3}{*}{$\begin{array}{l}\text { Integracja } \\
\text { społeczna }\end{array}$} & S9 & $\begin{array}{l}\text { przeciętny miesięczny dochód rozporządzalny na jedną } \\
\text { osobę w gospodarstwie domowym }\end{array}$ & $\mathrm{S}$ \\
\hline & S10 & $\begin{array}{l}\text { liczba osób korzystających z pomocy społecznej } \\
\text { na } 1 \text { tys. mieszkańców }\end{array}$ & $\mathrm{D}$ \\
\hline & S11 & wskaźnik zagrożenia ubóstwem relatywnym & $\mathrm{D}$ \\
\hline \multirow{3}{*}{$\begin{array}{l}\text { Dostęp } \\
\text { do rynku } \\
\text { pracy }\end{array}$} & S12 & wskaźnik zatrudnienia & $\mathrm{S}$ \\
\hline & S13 & stopa bezrobocia rejestrowanego & $\mathrm{D}$ \\
\hline & S14 & $\begin{array}{l}\text { liczba osób niepełnosprawnych w wieku produkcyjnym } \\
\text { (15-64 lat), u których po raz pierwszy stwierdzono nie- } \\
\text { pełnosprawność }\end{array}$ & $\mathrm{D}$ \\
\hline \multirow{3}{*}{ Edukacja } & S15 & liczba absolwentów wyższych uczelni na 1 tys. mieszkańców & $\mathrm{S}$ \\
\hline & S16 & $\begin{array}{l}\text { udział osób z wykształceniem podstawowym lub niepełnym } \\
\text { podstawowym wśród mieszkańców w wieku 25-64 lat }\end{array}$ & $\mathrm{D}$ \\
\hline & S17 & $\begin{array}{l}\text { udział osób z wykształceniem wyższym wśród mieszkań- } \\
\text { ców w wieku produkcyjnym }\end{array}$ & $\mathrm{S}$ \\
\hline \multirow{2}{*}{$\begin{array}{l}\text { Bezpie- } \\
\text { czeństwo } \\
\text { publiczne }\end{array}$} & S18 & $\begin{array}{l}\text { liczba ofiar śmiertelnych wypadków drogowych } \\
\text { na } 100 \text { tys. mieszkańców }\end{array}$ & $\mathrm{D}$ \\
\hline & S19 & liczba zarejestrowanych przestępstw na 1 tys. mieszkańców & $\mathrm{D}$ \\
\hline \multirow{2}{*}{$\begin{array}{l}\text { Zrówno- } \\
\text { ważona } \\
\text { konsumpcja }\end{array}$} & S20 & $\begin{array}{l}\text { emisja zanieczyszczeń do atmosfery ze stacjonarnych } \\
\text { źródeł wytwarzających zanieczyszczenia }\end{array}$ & $\mathrm{D}$ \\
\hline & S21 & $\begin{array}{l}\text { zużycie wody na potrzeby gospodarstw domowych } \\
\text { na } 1 \text { mieszkańca }\end{array}$ & $\mathrm{D}$ \\
\hline
\end{tabular}

Źródło: Opracowanie własne na podstawie danych Departamentu Statystyki Litwy [DSL]. 
Po uwzględnieniu przesłanek metytoryczno-statystycznych początkowy zestaw wskaźników indywidualnych zrównoważonego rozwoju w wymiarze społecznym został pomniejszony do 9 wskaźników: S3, S5, S9, S11, S13, S14, S15, S18 i S21. Każdy podobszar był reprezentowany przynajmniej przez jeden wskaźnik.

Badanie regresji dla współczynników zmienności tych 9 wskaźników indywidualnych pozwoliło określić, które zmienne decydują o istotnym zwiększeniu zróżnicowania, a które o jego istotnym zmniejszeniu. Otrzymane wyniki wskazują, że wpływ na istotne zwiększenie zróżnicowania wywierają kolejno następujące zmienne: demograficzny wskaźnik starości (S3), liczba absolwentów wyższych uczelni na 1 tys. mieszkańców (S15), ofiary śmiertelne wypadków drogowych na 100 tys. mieszkańców (S18) oraz zużycie wody na potrzeby gospodarstw domowych $\left(\mathrm{m}^{3}\right)$ na 1 mieszkańca (S21). Dla pozostałych zmiennych istotność pozostawała powyżej 0,1 .

Wartości obliczonych syntetycznych wskaźników zrównoważonego rozwoju w wymiarze społecznym dla okręgów Litwy w latach 2006-2016 zawiera tabela 2. Na podstawie średniej arytmetycznej i odchylenia standartowego z wartości skonstruowanych mierników dokonano podziału okręgów na cztery klasy typologiczne: o wysokim, średnim wyższym, średnim niższym i niskim poziomie sfery społecznej trwałego rozwoju okręgów. Za pomocą odcieni szarości oznaczono przynależność okręgów do klas typologicznych (tab. 2).

Zdolności dyskryminacyjne skonstruowanych mierników do podziału okręgów na klasy typologiczne są dosyć wysokie (tab. 2). Najwyższą wartość współczynnika G odnotowano dla roku $2012(0,539)$, a najniższą - dla roku $2008(0,301)$.

Analizując wartości skonstruowanych mierników, zauważa się dosyć dużą rozpiętość pomiędzy minimalną a maksymalną wartością syntetycznego miernika zrównoważonego rozwoju w wymiarze społecznym (tab. 2). Współczynnik zmienności w latach 2006-2016 przyjmował stabilną wartość (50\%)². Współczynnik asymetrii w badanym okresie przyjmował wartości dodatnie. Zróżnicowanie pozycji okręgów ze względu na skonstruowany miernik w latach 2006-2016 jest bardzo duże. Stabilną i wiodącą pozycję $w$ danych rankingach $w$ badanym okresie zajmował jedynie okręg wileński (pozycja 1). Mniej stabilne, ale wiodące pozycje ze względu na poziom zrównoważonego rozwoju w wymiarze społecznym zajmowały okręgi: kowieński (poz. 2/poz. 3), kłajpedzki (poz. 3/poz. 2). Dla pozostałych okręgów odnotowano dosyć duże zróżnicowanie pozycji w danych rankingach. Ogólnie poziom zrównoważonego rozwoju w sferze społecznej w $2016 \mathrm{r}$. w porównaniu z rokiem 2006 wzrósł. Świadczy o tym wzrost wartości syntetycznego miernika $\mathrm{w}$ badanym okresie.

2 Badania własne wykazały, że współczynnik zmienności syntetycznej miary skonstruowanej metodą Hellwiga zawsze przybiera wartość 50\%. Dla innych metod porządkowania liniowego (m.in. Perkala i TOPSIS) nie jest to charakterystyczne. 


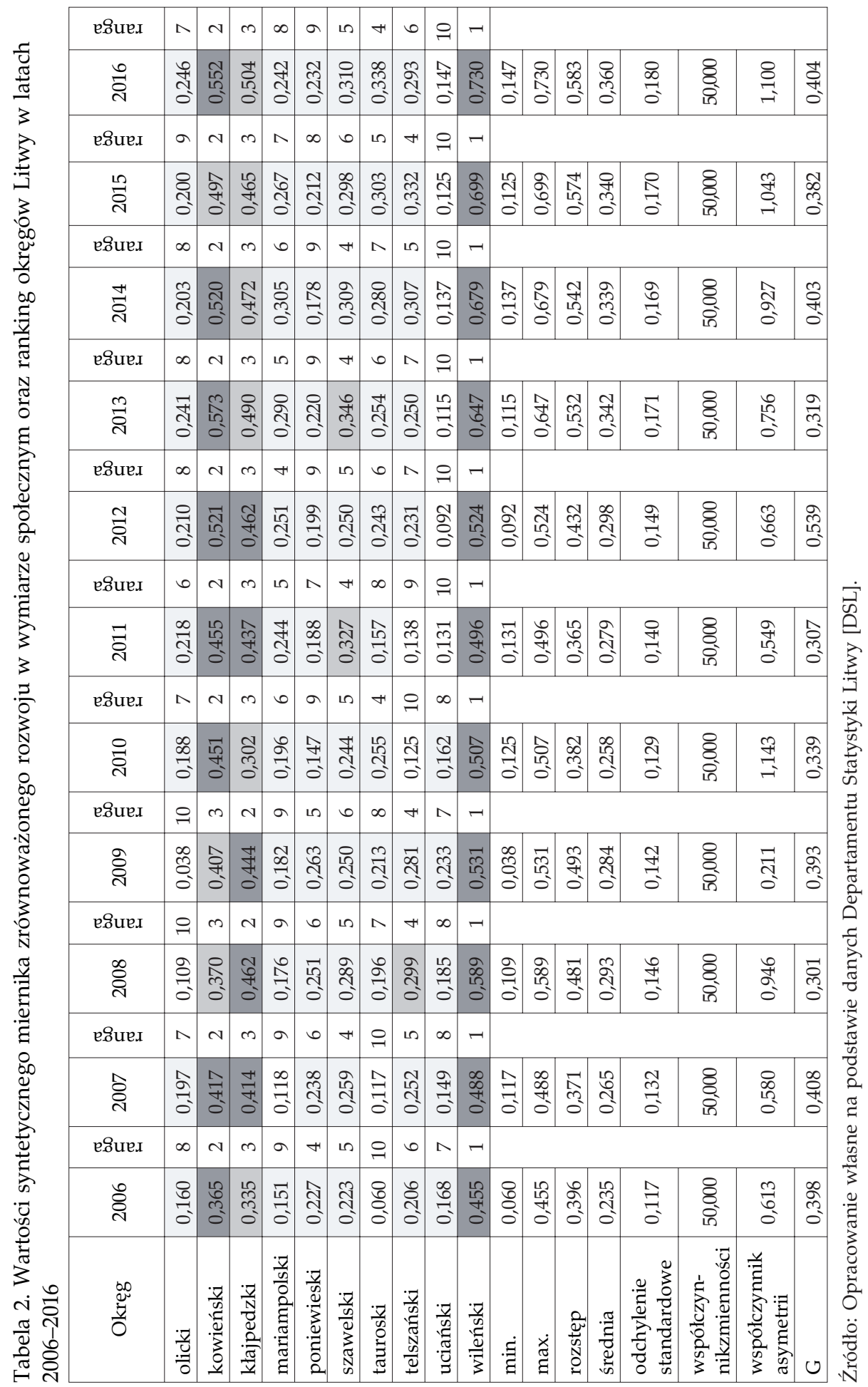


Wysoki poziom zrównoważonego rozwoju w sferze społecznej w latach 2006-2016 odnotowano jedynie w okręgu wileńskim. Wysoki i średni wyższy poziom w badanym okresie przeważał w okręgach: kowieńskim i kłajpedzkim. Pozostałe okręgi w latach 2006-2016 należały do trzeciej klasy typologicznej. Niski poziom zrównoważonego rozwoju w wymiarze społecznym przez większość badanych lat przeważał w okręgu uciańskim. Również przez kilka lat niski poziom sfery społecznej odnotowano $\mathrm{w}$ okręgach: olickim, tauroskim i telszańskim.

Analiza wartości skonstruowanego miernika zrównoważonego rozwoju w sferze społecznej w badanym okresie wskazuje na duże zróżnicowanie tempa i kierunku zmian zrównoważonego rozwoju okręgów Litwy. Najniższą wartość syntetycznego miernika odnotowano w 2009 r. dla okręgu olickiego $(0,038)$, a najwyższą w 2016 r. dla okręgu wileńskiego $(0,730)$.

Ocena zmian wartości syntetycznego miernika w latach 2006-2016 pozwala wyróżnić spadki i wzrosty poziomu zrównoważonego rozwoju w wymiarze społecznym dla poszczególnych okręgów. Tempo zmian wartości skonstruowanego miernika uzależnione było od roku i okręgu. Można wyodrębnić następujące okresy rozwoju w zakresie ładu społecznego dla okręgów Litwy:

- I okres: 2006-2008 - umiarkowany wzrost,

- II okres: 2009-2010 - spadek w większości okręgów,

- III okres: 2011-2013 - umiarkowany wzrost,

- IV okres: 2014-2015 - spadek w większości okręgów,

- V okres: 2016 - umiarkowany wzrost.

Przedstawienie zmian wartości syntetycznego miernika za pomocą wykresów pozwala zaobserwować trendy zmian (rys. 1).

I okres: W 2007 r. w porównaniu z 2006 r. w większości okręgów poziom zrównoważonego rozwoju w wymiarze społecznym wzrósł. Jedynie dla dwóch okręgów odnotowano spadek: mariampolskiego (o 0,034) i uciańskiego (o 0,019). W kolejnym roku sytuacja nie uległa zasadniczym zmianom. W 2008 r. w porównaniu z 2007 r. dla większości okręgów nastąpił większy wzrost wartości syntetycznego miernika. Największy wzrost poziomu ładu społecznego odnotowano w okręgu wileńskim (o 0,101), a największy spadek w okręgach: olickim (o 0,089) i kowieńskim (o 0,047).

II okres: W 2009 r. dla połowy okręgów nastąpił spadek poziomu zrównoważonego rozwoju w sferze społecznej. Sytuację tę należy tłumaczyć wpływem światowego kryzysu gospodarczego, który nastąpił w 2008 r. Największy spadek wartości syntetycznego miernika w 2009 r. w porównaniu z 2008 r. odnotowano dla okręgu olickiego (o 0,071), a najmniejszy - dla okręgów kłajpedzkiego (o 0,018) i telszańskiego (o 0,018). W $2010 \mathrm{r}$. spadki i wzrosty syntetycznego miernika rozwoju społecznego były o wiele większe niż przed rokiem. Pewnym wyjaśnieniem takiego zachowania jest wpływ europejskiego kryzysu, który trwał w latach 2009-2011 
[Majewska, 2017]. Największy spadek wartości tego miernika zaobserwowano w okręgach: telszańskim (o 0,156), kłajpedzkim (o 0,142) i poniewieskim (o 0,116), natomiast największy jego wzrost w $2010 \mathrm{r}$. w porównaniu z 2009 r. odnotowano w okręgu olickim (o 0,150$)$.

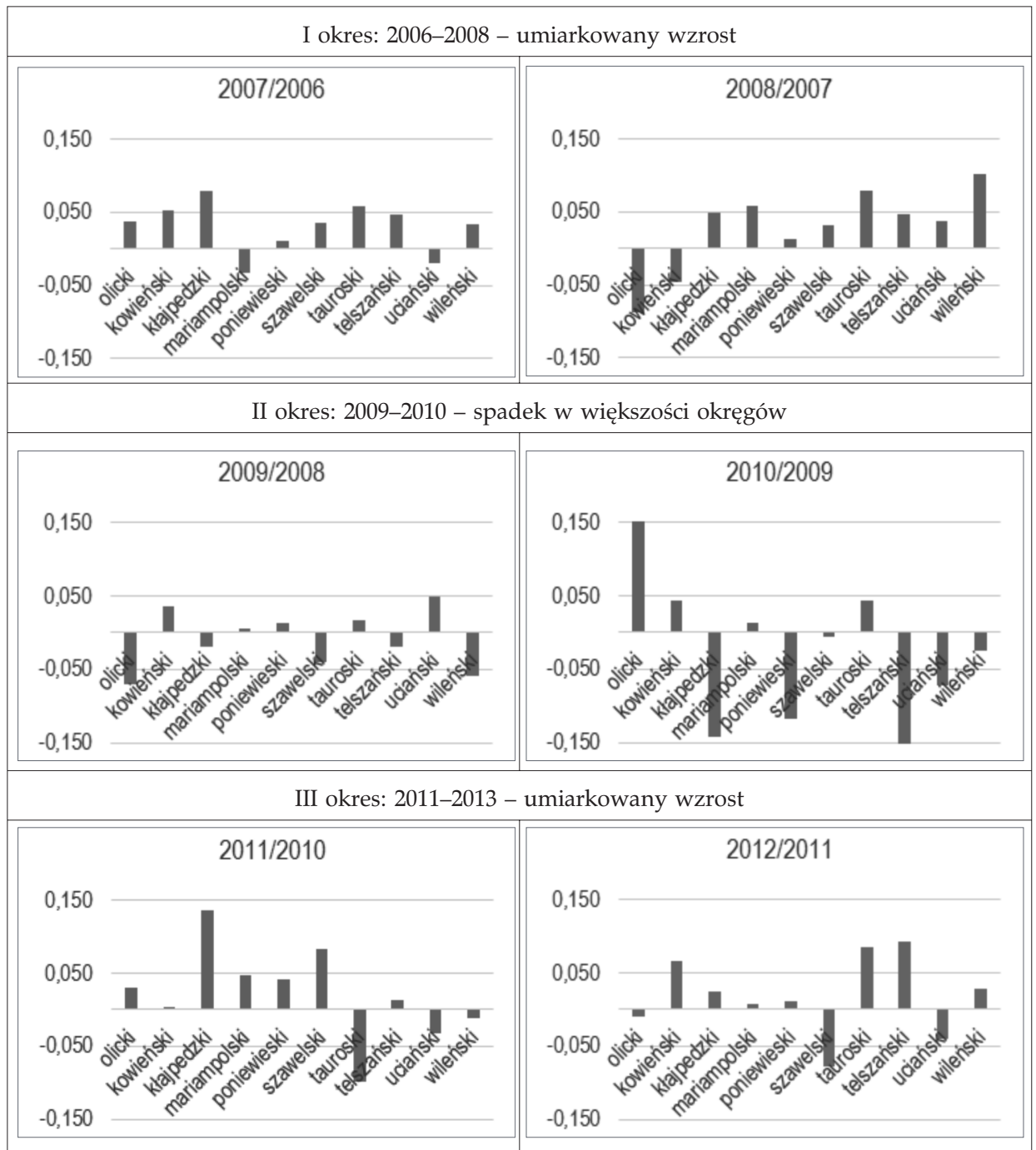




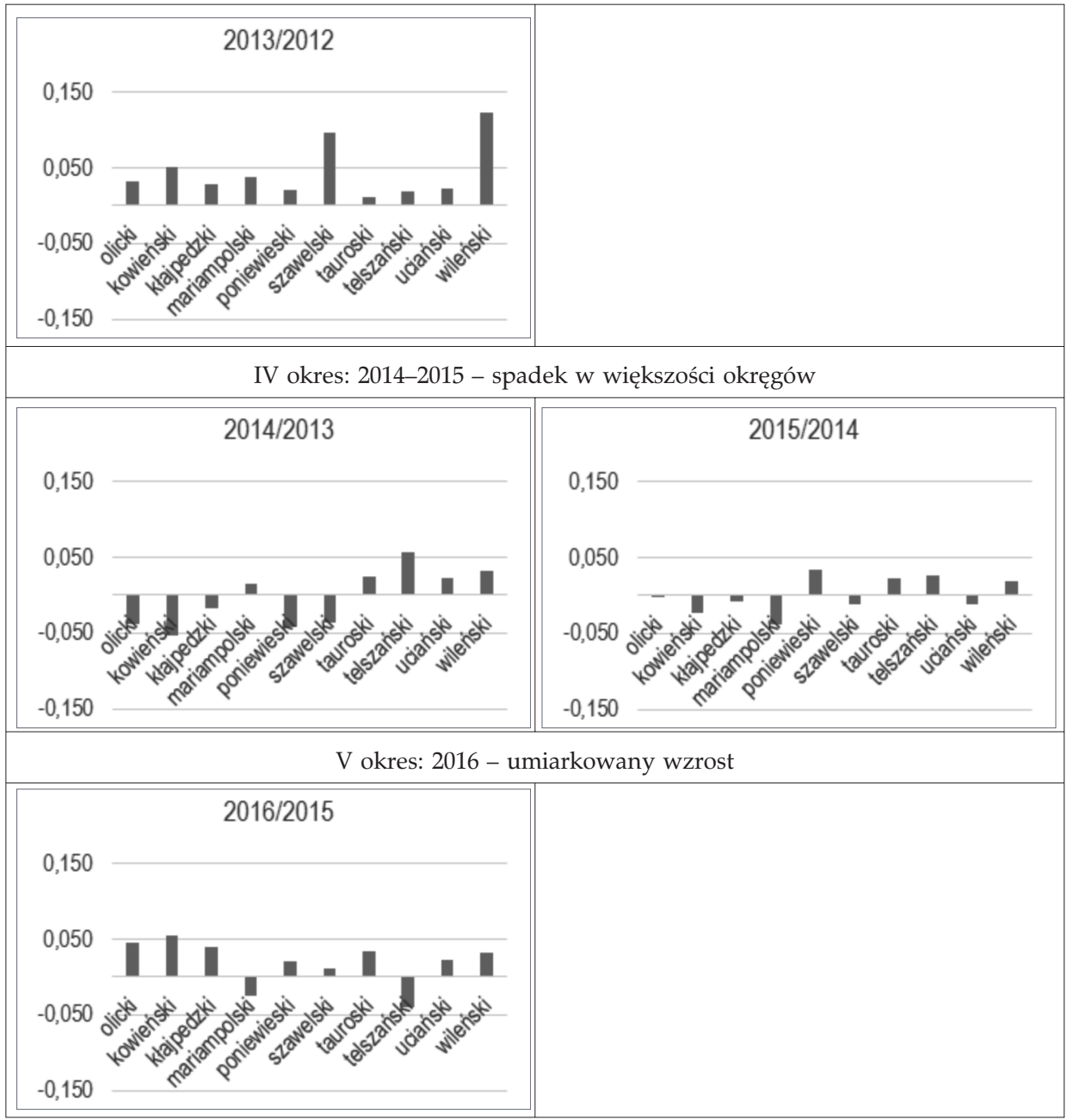

Rysunek 1. Zmiany wartości syntetycznego miernika zrównoważonego rozwoju w wymiarze społecznym dla okręgów Litwy w latach 2006-2016

Źródło: Opracowanie własne na podstawie danych Departamentu Statystyki Litwy [DSL].

III okres: W 2011 r. w sferze społecznej w okręgach nastąpiła poprawa. W większości okręgów w porównaniu z rokiem poprzednim odnotowano wzrost pozio$\mathrm{mu}$ zrównoważonego rozwoju $\mathrm{w}$ sferze społecznej. Spadek nastąpił tylko w trzech okręgach: tauroskim (o 0,098), uciańskim (o 0,032) i wileńskim (o 0,011). W 2012 r. w porównaniu z 2011 r. poziom sfery społecznej trwałego rozwoju okręgów Litwy utrzymywał się na zbliżonym poziomie jak przed rokiem. Interesujące, że dla okręgów: tauroskiego, telszańkiego i kowieńskiego odnotowano podobny przyrost wartości skonstruowanego miernika. Natomiast największy spadek poziomu wymiaru społecznego w $2012 \mathrm{r}$. w porównaniu z 2011 r. nastąpił 
w okręgu szawelskim (o 0,077). W kolejnym roku we wszystkich okręgach zaobserwowano wzrost poziomu sfery społecznej trwałego rozwoju. W 2013 r. w porównaniu z 2012 r. największy przyrost wartości syntetycznego miernika odnotowano w okręgach: wileńskim (o 0,123) i szawelskim (o 0,096).

IV okres: W 2014 r. w okręgach Litwy nastąpiło pogorszenie sytuacji społecznej. Według raportu Międzynarodowego Funduszu Walutowego (TVF) w latach 2010-2014 liczba mieszkańców Litwy w wieku produkcyjnym zmniejszyła się prawie o $2 \%$ każdego roku, a połowę tej liczby stanowili emigranci. Problem starzenia się społeczeństwa Litwy ujemnie wpłynął więc na poziom sfery społecznej zrównoważonego rozwoju [Tučas, 2018]. W 2014 r. w porównaniu z 2013 r. spadek wartości syntetycznego miernika odnotowano w pięciu okręgach: olickim (o 0,038$)$, kowieńskim (o 0,053), kłajpedzkim (o 0,017), poniewieskim (o 0,042) i szawelskim (o 0,037). W 2015 r. nastąpił dalszy spadek wartości syntetycznego miernika wymiaru społecznego. Przyrost wartości syntetycznego miernika w 2015 r. w porównaniu z 2014 r. również był mniejszy niż przed rokiem - największy w okręgu poniewieskim (o 0,034$)$.

V okres: W 2016 r. w porównaniu z 2015 r. w większości okręgów poziom zrównoważonego rozwoju w sferze społecznej wzrósł. Jedynie dla dwóch okręgów odnotowano spadek wartości syntetycznego miernika: telszańskiego (o 0,039) i mariampolskiego (o 0,025$)$.

\section{Podsumowanie}

Cały czas brakuje prac badawczych stosujących odmienne metody badawcze w analizie zrównoważonego rozwoju Litwy w wymiarze społecznym.

Podsumowując przeprowadzone badania, można zauważyć wzrost zróżnicowania między okręgami poziomu rozwoju społecznego w kontekście zrównoważonego rozwoju. W 2016 r. zaobserwowano jednak wzrost poziomu rozwoju społecznego we wszystkich okręgach w porównaniu z 2006 r. Zastosowanie metody porządkowania liniowego pozwoliło nie tylko ustalić ranking poszczególnych okręgów, ale i określić poziom rozwoju społecznego dla każdego okręgu w latach 2006-2016. Klasyfikacja okręgów do typologicznych klas i ocena zmian wartości skonstruowanego miernika potwierdzają stabilną i wiodącą pozycję okręgu wileńskiego pod względem poziomu zrównoważonego rozwoju w sferze społecznej. Drugie miejsce należy do okręgu kowieńskiego, a trzecie do okręgu kłajpedzkiego. Pozostałe okręgi w badanym okresie charakteryzowało duże zróżnicowanie tempa oraz kierunku rozwoju sfery społecznej zrównoważonego rozwoju.

Przeprowadzona analiza pozwoliła także wyodrębnić okresy zrównoważonego rozwoju w sferze społecznej okręgów Litwy: I okres: 2006-2008 - umiarkowany wzrost, II okres: 2009-2010 - spadek w większości okręgów, III okres: 
2011-2013 - umiarkowany wzrost, IV okres: 2014-2015 - spadek w większości okręgów, V okres: 2016 - umiarkowany wzrost.

Największy udział w zrównoważonym rozwoju kraju mają jego mieszkańcy. Aby społeczeństwo uświadomiło sobie i zrozumiało zasady zrównoważonego rozwoju, potrzebny jest nie tylko czas, ale i inwestycje. Zróżnicowanie poziomu zrównoważonego rozwoju w poszczególnych okręgach zależy od wielu czynników, takich jak: liczba mieszkańców - przede wszystkim w wieku produkcyjnym, poziom i wykształcenie kapitału ludzkiego, dostępność infrastruktury społeczno-technicznej oraz integracyjna polityka regionalna państwa, polegająca na niwelowaniu różnic rozwojowych pomiędzy okręgami.

Wyniki badań można wykorzystać w tworzeniu oraz monitorowaniu regionalnych strategii zrównoważonego rozwoju. Pewne utrudnienie stanowi brak ciągłości oraz dostępności danych statystycznych w ujęciu regionalnym. Zastosowana metoda badawcza i właściwie dobrane indywidualne wskaźniki wymiaru społecznego to jedna z propozycji badania poziomu zrównoważonego rozwoju w ujęciu czasowym i przestrzennym. Kontynuacją tych badań będzie analiza poziomu zrównoważonego rozwoju w sferze gospodarczej okręgów Litwy w latach 2006-2016.

\section{Bibliografia}

Barasaitè A., 2016, Darnaus vystymosi principu analizè ir vertinimas, Mykolo Romerio Universitetas, Vilnius.

Bartniczak B., 2012, Modut wskaźników zrównoważonego rozwoju w Banku Danych Lokalnych, Wiadomości Statystyczne, nr 9.

Bell S., Morse S., 2000, Sustainability Indicators. Measuring the Immeasurable, Earthscan, London. Čiegis R., 2004, Ekonomia ir aplink. Subalnasuotos pletros valdymas, VDU leidykla, Kaunas. Čiegis R., 2008, Darnus ekonomikos vystymasis, VšI Šiaulių universiteto leidykla, Šiauliai.

Darnaus vystymosi tikslai, 2016, Naujienlaiškis \#4, Media4Development, eurohouse.lt/wpcontent/uploads/2016/12/Naujienlaiskis-4.pdf [dostęp: 08.02.2018].

Dobrzańska B., 2006, Polityka ochrony środowiska, [w:] Obszary integracji Unii Europejskiej. Wybrane zagadnienia, red. E. Sulima, Wydawnictwo Uniwersytetu w Białymstoku, Białystok.

DSL, Departament Statystyki Litwy, http://osp.stat.gov.lt/ [dostęp: 03.02.2018].

Galkute L., 2005, Darnaus vystymosi paradigmos projekcija mokykloje, Acta Paedagogica Vilnensia, 14 .

Kozłowski S., 2008, Zrównoważony rozwój - program na jutro, Abrys, Poznań - Warszawa.

Krankalis R., 2010, Darnaus vystymosi strategijos igyvendinimas Radviliškio rajono švietimo institucijose, Ekonomika ir vadyba. Aktualijos ir perspektyvos, nr 3, www.su.lt/bylos/mokslo_leidiniai/ekonomika/2010_3_19.../krankalis_kuciene.pdf [dostęp: 04.02.2018].

Majewska E., 2017, Okresy kryzysu na rynkach strefy euro w latach 2004-2016, Finanse, Rynki Finansowe, Ubezpieczenia, nr 1.

Malina A., 2014, Wielowymiarowa analiza przestrzennego zróżnicowania struktury gospodarki Polski wedtug województw, Zeszyty Naukowe Wydawnictwa Akademii Ekonomicznej w Krakowie, nr 162. 
Mazajevaite R., 2016, Nacionalinès darnaus vystymosi strategijos igyvendinimas Lietuvos apskrityse. Šiauliu ir Telšiu apskričiu lyginamoji analize, Šiaulių Universitetas, Šiauliai.

Młodak A., 2006, Analiza taksonomiczna w statystyce regionalnej, Wydawnictwo Difin, Warszawa.

Morozova O.V., 2009, Koncepcja zrównoważonego rozwoju w teorii ekonomii, [w:] Wpływ idei zrównoważonego rozwoju na politykę państwa i regionów, red. B. Poskrobko, Wydawnictwo Wyższej Szkoły Ekonomicznej w Białymstoku, Białystok.

Nowak E., 1990, Metody taksonomiczne w klasyfikacji obiektów społeczno-gospodarczych, Polskie Wydawnictwo Ekonomiczne, Warszawa.

Paulikas V., Lazdinis I., 2006, Darni plètra - darni visuomene, Darnaus vystymosi strategija ir praktika, Mokslo darbai, Mykolo Romerio Universitetas, Vilnius.

Pearce D., 1987, Foundations of an ecological economics, Ecological Modelling, vol. 38.

Perło D., 2014, Modelowanie zrównoważonego rozwoju regionów, Wydawnictwo Uniwersyteckie Trans Humana, Białystok.

Perło D., Roszkowska E., 2011, Zastosowanie wybranych metod klasyfikacji do analizy zrównoważonego rozwoju, Zeszyty Naukowe Uniwersytetu Ekonomicznego w Poznaniu, nr 176.

Ponikowski H., 2007, Metafizyczne dociekania podstaw zrównoważonego rozwoju, [w:] Problemy interpretacji i realizacji zrównoważonego rozwoju, red. B. Poskrobko, G. Dobrzański, Wydawnictwo Wyższej Szkoły Ekonomicznej w Białymstoku, Białystok.

Roszkowska E., Filipowicz-Chomko M., 2016, Ocena rozwoju społecznego województw Polski w latach 2005-2013 w kontekście realizacji koncepcji zrównoważonego rozwoju z wykorzystaniem metody TOPSIS, Ekonomia i Środowisko, nr 2.

Roszkowska E., Karwowska R., 2014, Wielowymiarowa analiza poziomu zrównoważonego rozwoju województw Polski w 2010, Economics and Management, nr 1.

Sachs I., 2004, Inclusive development strategy in an era of globalization, ILO, Geneva.

Słownik DSL, http://osp.stat.gov.lt/statistikos-terminu-zodynas [dostęp: 05.02.2018].

Sokołowski A., 1984, Wybrane zagadnienia pomiaru i ważenia cech $w$ taksonomii, Zeszyty Naukowe Akademii Ekonomicznej w Krakowie, nr 203.

Strahl D. (red.), 2006, Metody oceny rozwoju regionalnego, Akademia Ekonomiczna, Wrocław.

Štreimikienė D., 2014, Darnus vystymasis. Teorija ir praktika, Vilniaus Universitetas, Vilnius.

Štreimikienė D., Vasiljevienė N., 2004, Etiniai darnaus vystymosi aspektai ir jų ryšys su socialinemis ir aplinkosauginemis darnaus vystymosi dimensijomis, Organizaciju vadyba: sisteminiai tyrimai, $\mathrm{nr} 32$.

Tučas R., 2018, Lietuvos gyventojų amžiaus demografinès struktūros kaitos prognozé 2017-2021 m., Lietuvos švietimo ir mokslo ministerija, Vilnius, https://www.smm.lt/../Tucas_R_Demografines_prognozes_SMM_2018_01_18.pdf [dostęp: 05.02.2018].

Uchwała z dnia 19 września 2003 r., Dz. U., ñ 89-4029, poz. 1160, z późn. zm., Del nacionalines darnaus vystymosi strategijos patvirtinimo ir igyvendinimo, https://www.e-tar.lt/ portal/lt/legalAct/TAR.EAC62D7F8C15/TAIS_396083 [dostęp: 04.02.2018].

Wskaźniki Zrównoważonego Rozwoju (Darnaus vystymosi rodikliai), 2016, DSL, https:// osp.stat.gov.lt/darnaus-vystymosi-rodikliai [dostęp: 04.02.2018].

R. Lašakevič (『) r.klukowska@uwb.edu.pl

Wydział Ekonomiczno-Informatyczny w Wilnie, Uniwersytet w Białymstoku,

Tyzenhausu g. 10-19, Vilnius, LT-02107, Litwa 